resistant Stuphylococcus aureus for the 1990s and effective control measures. Am J Med. 1991;91 (suppl 3B):221S-225S.

2. Schaberg DR, Culver DH, Gaynes RI? Major trends in the microbial etiology of nosocomial infection. Am JMed. 1991;91:72S $75 \mathrm{~s}$.

3. Gelmi M, Forest I, Ravizzola G, et al. Antibiotic resistances and plasmids in Staphylococcus aureus from Italian hospitals. J Med Microbiol. 1987;23:111-118

4. Pavillard P, Harvey K, Douglas D, et al. Epidemic of hospitalacquired infection due to methicillin-resistant Staphylococcus aureus in major Victorian hospitals. Med J Aust. 1982;1:451-454.

5. Bradley JM, Noone P, Townsend DE, Grubb WB. Methicillinresistant Staphylococcus uureus in a London hospital. Lancet. 1985;i:1493-1495.

6. Wey SB, Cardo DM, Walker E, Carratu FP, Saes AC. Distribution and analysis of 8,268 nosocomial infections at the Hospital Sao Paulo: 1985 to 1989. Rev Hosp Sao Puulo.1990;1:169-174.

7. Rodrigues JN, Amaral JLG, Pignatari A, et al. Molecular epidemiology and antimicrobial susceptibility testing of quinoloneresistant Stuphylococcus aureus strains isolated in Brazil. Diagn Microbiol Infect Dis. 1993;16:9-16.

8. Thompson RL, Cabezudo IC, Wenzel RI? Epidemiology of nosocomial infections caused by methicillin-resistant Staphylococcus uureus. Ann Intern Med. 1982;97:309-317.

9. Sesso R, Draibe $S$, Castelo A, et al. Staphylococcus aureus skin carriage and development of peritonitis in patients on continuous ambulatory peritonial dialysis. Clin Nephrol. 1989:31:264-268.

10. National Committee for Clinical Laboratory Standards. Approved
Standard, M7-A2: Standard Methods for Dilution Antimicrobial Susceptibility Tests for Bacteria that Grow Aerobically. 2nd ed. Villanova, PA NCCLS; 1990.

11. Nahaie MR, Goodfellow M, Harwood CR. A rapid screening procedure for staphylococcal plasmids. J Microbiol Methods. 1984;2:73-81.

12. Finch RG, Hawkey PM, Towner KJ, eds. RP-59500, a semisynthetic injectable streptogramin antibiotic. J Antimicrob Chemother 1992;30(suppl A): 1-131.

13. Haley RW, Hightower AW, Khabbaz RF, et al. The emergence of methicillin-resistant Staphylococcus uureus infections in United States hospitals: possible role of the house staff-patient transfer circuit. Ann Intern Med. 1982;97:297-308.

14. Lyon BR, Iuorio JL, May JW, Skurray RA. Molecular epidemiology of multiresistant Staphylococcus uureus in Australian hospitals. JMed Microbiol. 1984:17:79-89.

15. Townsend DE, Ashdown N, Bradley JM, Pearman JW, Grubb WB. Australian methicillin-resistant Stuphylococcus aureus in a London hospital. Med J Aust. 1984;141:339-340.

16. Zuccarelli AJ, Roy I, Harding GP, Couperus JJ. Diversity and stability of restriction enzyme profiles of plasmid DNA from methicillin-resistant Staphylococcus uureus. J Clin Microbiol. 1990;28:97-102.

17. Doebbeling BN, Pfaller MA, Hollis RI, et al. Restriction endonuclease analysis of Staphylococcus uureus plasmid DNA from three continents. EurJ Clin Microbiol Infect Dis. 1992;11:4-8.

\title{
Reintroduction of Discontinued TB Drugs to Combat Epidemic
}

\section{by Gina Pugliese, RN, MS Medical News Editor}

Mary Pendergast, senior advisor to the commissioner of the Food and Drug Administration (FDA), reported at the recent World Congress on Tuberculosis in Bethesda, Maryland, that the FDA is concerned with the need for more effective drugs for treating tuberculosis because many of the existing antituberculosis drugs are either unavailable or in insufficient supply. She explained that the FDA is currently tracking down sources for existing antitu- berculosis drugs throughout the world, as well as urging United States drug manufacturers to keep antituberculosis drugs on the market, bring back discontinued drugs, and seek approval for new ones. The FDA is also planning to expedite the review of antituberculosis drugs, biologics, and devices.

Emergency supplies of streptomycin sulfate are being distributed through the Centers for Disease Control and Prevention (CDC) as an investigational drug until drug production can resume in the United States. Two generic drugs were approved last year for tuberculosis treatment, a form of amikacin and pyrazinamide. Additionally, the only injectable form of isoniazid, Nydrazid, has just been reintroduced at the request of the FDA and CDC. It will be useful for patients who are unable to take pills.

The FDA's willingness to accept foreign data for approval of drugs from outside the United States is evidenced by the drug Rifater. This agent is a combination of rifampin, isoniazid, and pyrazinamide and would make compliance with therapy much easier. 